\title{
Industry Lifecycle of Nigeria's Telecom Sector: Possible Trajectories after Deregulation
}

\author{
Onochie Jude Dieli \\ Prairie View A\&M University
}

This current study examines Nigerian telecom sector status change caused by the arrival of a new wireless mobile technology. Nigeria's telecom industry had been a state owned industry due to its highfixed cost of operation until it was deregulated in 1999. Availability of wireless mobile phone technology drastically reduced the high fixed cost of operation which paved the way for deregulation. The study used data obtained from the Nigerian Communication Commission. The study finds that Nigeria's telecom sector after it was deregulated follows typical industry life-cycle stages as shown in Gort and Klepper (1982). Although, it has not reached the shakeout stage (a sharp decline in the number of firms). It, however, shows signs of two possible trajectories after stage three. They are steady or shakeout states. These findings help the Nigerian Communication Commission form a better guideline to predict the sector.

Keywords: industry lifecycle, wireless mobile phone technology, telecom industry, deregulation policy

\section{INTRODUCTION}

This paper studies the patterns of Nigeria's telecom industry lifecycle after deregulation. ${ }^{1}$ The industry was fully deregulated in 1999. The law that established the deregulation policy is Decree 75. Within the period 1960 to 1985, Nigeria's telecom sector was made up of Posts and Telecommunications. Later on in 1985, the Department of Posts and Telecommunications and the Nigerian External Telecommunications (NET) merged to form NITEL. This was a limited liability company. It administered both internal and external telecommunications services in Nigeria. It is important to mention that most of NITEL's funding came from the Federal Government through the Ministry of Communication. It was not a profit oriented institution at first but when the burden of sponsorship became too much for the government, they introduced the policy of commercialization in 1987 so that NITEL could become selfsustaining. The policy was a disaster because of many reasons alleged such as inefficient management partly due to unproductive use of capital and partly because of inefficient billing system. The enterprise could not pay its bills and was running at a loss. It depended on government subsidies for sustenance. NITEL management believed that by adopting appropriate technology most of the technical aspects of these problems could be solved but they persisted. As a result of changing global economic dynamics, Nigeria's government opted for the policy of deregulation in the telecom industry which was until 1992 a natural monopoly.

With the implementation of deregulation policy in Nigeria's telecom industry, it become imperative to find if the telecom industry has followed typical industry lifecycle pattern as modelled by Gort and 
Klepper. This will assist policy makers in formulation of relevant policy to keep the industry vibrant and competitive. Deregulation policy opens up industry for competition. This results in increase in quantity of output (number of phone lines), number of carriers (number of firms), fall in price as found by some scholarly models ${ }^{2}$. According to Gort and Klepper, a typical evolution of the number of carriers, output and price in an industry is expressed in five stages. The top graph in figure 1 shows Gort and Klepper's five stages of an industry's life cycle while the bottom graph shows the three phases of life-cycle by Dinlersoz and Macdonald: adopted from Dinlersoz \&Macdonald, 2009). Both models have meeting points and are saying the same thing. This work covered the period of 1999 to 2016. I ask, does the Nigerian telecom industry follow typical industry-lifecycle stages? If yes, is it at what stage or what are the next trajectories?

\section{TYPICAL STAGES OF INDUSTRY LIFE-CYCLE}

The number of carriers, size, price and output in a particular industry alters as industry evolves along the lifecycle stages. The output and employment distributions also differ greatly but also have strong inter-industry features. This evolvement is dependent on the stage of the lifecycle. These stages are growth, shakeout, maturity or decline. These dynamics have implications for theories of industry evolution (Dinlersoz and MacDonald, 2009).

This lifecycle view of industries was first developed by Gort \& Klepper. In 1982, established that manufacturing industries, in spite of many variations in production technique, raw materials, the structure of the market and regulations pass through well-known and the same lifecycle stages. The claim was later explained extensively. Scholars such as Klepper\& Grady (1990), Klepper\& Simons (2000), Agarwal \&Gort (1996, 2001), and Simons (2001) modified and expanded this. The major finding of these works, with very few exceptions, is that the lifecycle and the number of operators in an industry is nonmonotonic. This is shown in figure 1. Initially, the number of firms will increase with rapidity, after which the 'shakeout' phase kicks-off. It is during this latter stage that firms leave the industry after which the industry stabilizes. This process induces increased total industry output which is accompanied by falling prices. In contrast, the size distribution of firms in an industry within the phases of its lifecycle has attracted varying attention in economic literature. Cabral and Mata (2003), in their study of entrants in the manufacturing industry of Portugal for a period of eight years, revealed the evolution pattern of firm size distribution in the firm lifecycle. This is a kind of disaggregated lifecycle analysis where the firm's rather than the industry's lifecycle is evaluated. They found that firms (entrants) experience growth and selection. 


\section{FIGURE 1}

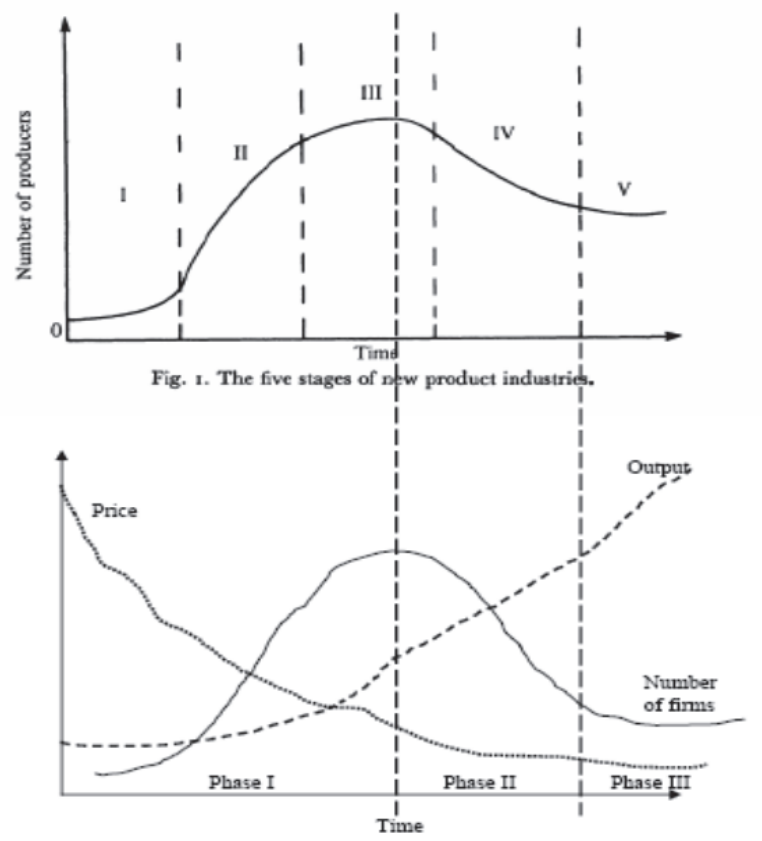

This is a typical evolution of the number of carriers, output and price in an industry. The top graph shows Gort and Klepper's five stages of an industry's life cycle while the bottom graph shows the three phases of life-cycle by Dinlersoz and Macdonald: adopted from Dinlersoz \& Macdonald, 2009).

Jovanovich and Macdonald (1994) used data of the US automobile tire industry of the period 19101920 to confirm the industry lifecycle stages. In this period, several key inventions appeared. It was found that firms that implemented inventions experienced growth in value and output. However, others that did not comply with the new invention were part of the mass exodus. The "shakeout" in the USA automobile tire industry is technology based. This is also consistent with what stock price data reveal about profit opportunities in the future of the tire industry. It predicted that the future of the industry was not all rosy for the incumbents. It asserted that early adoption of new technology could be very rewarding. There was another explanation for the automotive industry shakeout that says it was caused by the dwindling fortunes of the industry. However, this could not be substantiated by the timing of the shakeout in the tire industry.

Klepper and Simons (2005) found in their analyses of innovation that there was a positive correlation between early entry and the survival of innovators. And that there is the tendency for early entrants to innovate. They based their findings by analyzing the data on entry, exit and innovation from US automobiles, tires, televisions and penicillin industries. They concluded that a particular technological breakthrough does not trigger a shakeout; rather it is part of industry competition. In this competitive process, firms seek for dominance of the market through innovation and early entrants strive to dominate. Weaker firms, therefore, exit the industry (shakeout) and the stronger enjoy prosperity. This is, however, typical of industry lifecycle. In another development, Mazzucato (2002), evaluated two technologies and two industries namely an old high-tech industry and a new high-tech industry. They are the US auto industry from 1899-1929 and US PC industry 1974-2000. An assessment of the co-evolution of industrial and financial dynamics of these two industries in their early development was done. It was found that both industries experienced a high degree of turbulence during the first 30years. This included high entry rate and exit rate. It also experienced short life-spans of firms, and drastic innovation and rapidly decreasing prices. On the financial side, both industries experienced volatility of stock. 
Carree and Thurik (2000) presented a fresh model in industry evolution. This was applied using data from the US tire industry and the period covered was from 1913 to 1973. They found that it followed the usual industrial lifecycle. The shakeout stage that occurred was not as a result of any known innovation. They observed that the shakeout was triggered by a great and constant price competition in the tire industry. This was as result of overshooting in the number of firms and a decline in demand for tires during the great depression.

The Nigerian telecom industry has NITEL as incumbent and as at phase 1 of its lifecycle it is exhibiting the characteristics predicted in phase 1 of figure 1 One of its features is an increase in the number of carriers from 1 firm (NITEL) in 1999 to 25 firms in 2016 and more entrants are expected after which a shakeout may take place with a probable industry stabilization to follow. There was increase in number of telephone lines (output) from four hundred thousand lines in 1999 to over two hundred million lines in 2016. It is presently in stage three full of characteristics of that stage as model predicted.

However, it is necessary to indicate here that the over-interference of the regulatory body - NCC through setting of strange, anti-competitive guidelines such as five percent geographical spread within one year of operation might influence the patterns of Nigeria's telecom industry lifecycle, dynamics and evolution. So, to answer the question, does Nigeria telecom industry follow typical industry Life- Cycle stages?" It will be proper to state that Nigeria telecom industry evolution after deregulation is in consonance with the proven industry life-cycle stages. Klepper \& Gort (1982) developed five stages of life-cycle in an industry. Dinlersoz \& Glenn Macdonald (2009) established three phases which when merged explains industrial life-cycle evolution. Each stage has its own characteristic. Nigeria telecom industry is at stage 3 as stated above. Perhaps, tending towards its shake-out or stable states. These stages are characterized by rise in number of firms because of removal of entry barriers and fall in cost of production; increase in industrial capacity (output) because of entries of new firms and fall in product price emanating from competition. The stages are expected to be with or without shake-out. This is because the GSM market shares are already distributed among the top four firms. Studying seventeen years of post-deregulation experience of Nigeria's telecom sector, it is observed that original investors sell their equities in the firms to new investors and they usually change the names of the firm and no firm has exited. Here is the predicted trend of Nigeria's telecom industry life cycle. It is presently at the dark dot position in its life cycle and has the two possible trajectories to follow in its life-cycle as shown in figure below.

FIGURE 2

POSSIBLE TRAJECTORY OF NIGERIA'S TELECOM INDUSTRY LIFE CYCLE

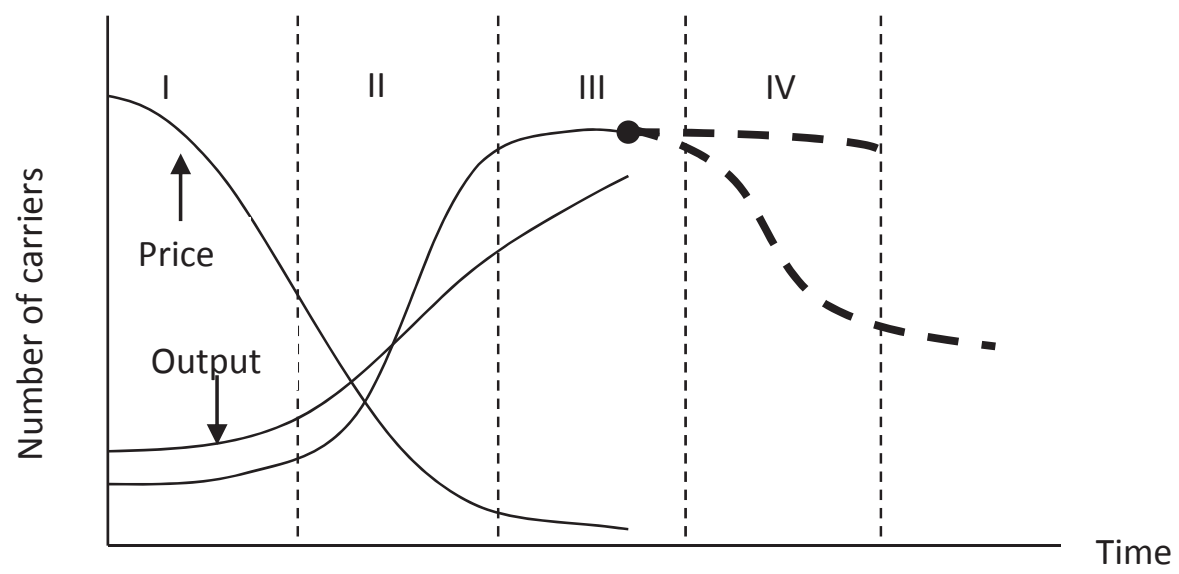

The anticipated life cycle of the Nigerian telecom industry (Gort\&Klepper model,1982) 


\section{CONCLUSION}

In summary, innovation and competition arising from deregulation led to a fall in price and a constant increase in the number of competitors until 2010 (Stage 2 of the industry's lifecycle) and constant rise in output. The Nigerian data showed that before the deregulation, it was costing about 25 naira/min to make a domestic call within a city, 150naira/min inter-Nigerian states and 250naira/min or more internationally but post deregulation data showed a drastic reduction in the domestic and international billing rates. According to the data, it now costs less than 4naira/min for domestic calls and less than $20 \mathrm{naira} / \mathrm{min}$ for international calls. The model predicts fall in product price engendered by competition which has been strongly supported by Nigeria data set. This data set source is NITEL billing receipts and billing receipts of the current players in the Nigeria telecoms industry such as MTN, GLO, Airtel, Etisalat, Starcomm, Multilinks and etc.

Empirical evidence and studies have made it crystal clear that deregulation of a natural monopoly increases the number of firms participating in an industry and reaffirmed by Gort \&Klepper model. NITEL was the sole service provider and incumbent in Nigeria's telecoms industry before deregulation of the sector. The number of telecoms carriers (firms) increased from 1 firm in 1999 to a total of 25 firms in 2015 which include mobile GSM, Mobile CDMA and Fixed and Fixed wireless. The Nigeria telecom industry prior to the implementation of the deregulation policy had only NITEL, a government monopoly, as the only firm operating in the industry which up till 1999 could give Nigeria, a country of about 160 million people, 450,000 telephone lines but with deregulation, Nigeria can boast of 214,760,406 million functional phone lines (NCC, 2015).

However, the number of firms in the telecom industry has remained constant for the past four years at twenty-five. This might be signaling the peak stage (Stage 3 of industry lifecycle). A decline in the number of firms, i.e., a shakeout, (stage 4 of the industry's lifecycle) according to Gort and Klepper, has not been observed yet. Whatever may be the case, it is important to state here once more that the deregulation of the natural monopoly NITEL was made possible in Nigeria by the availability of mobile phone technology and the sector follows standard industry lifecycle pattern. As observed in the trajectory, it has two possible outcomes after stage three: stable state or shake out before stability.

\section{ACKNOWLEDGEMENT}

The Ryoichi Sasakawa Young Leaders Fellowship Fund, Nippon Foundation Tokyo Japan sponsored and provided the funding for the study at Howard University, Washington, DC USA.

\section{ENDNOTES}

1. Removal of restrictions or regulations in an industry (telecom industry)

2. In 1982, Gort and Klepper built models that proved those claims right and Dinlersoz and MacDonald (2009) similarly established theirs, Jovanovic and Hopenhayn had their models in 1982 and (1992) respectively, SCT (Structure-Conduct-Performance) etc. 


\section{REFERENCES}

Agarwal, R., \& Audretsch, D. B. (2001). Does entry size matter? The impact of the lifecycle and technology on firm survival. The Journal of Industrial Economics, 49(1), 21-43.

Cabral, L. M. B., \& Mata, J. (2003). On the evolution of the firm size distribution: facts and theory. The American Economic Review, 93(4), 1075-1090.

Carree, M. A., \& Thurik, A. R. (2000). The life-cycle of the U. S. tire industry. Southern Economic Journal, 67(2) 254-278.

Dinlersoz, E.M., \& MacDonald, G. (2009). The industry lifecycle of the size distribution of firms. Review of Economic Dynamics, 12(4), 648-667.

Gort, M., \& Klepper, S. (1982). Time paths in the diffusion of product innovations. The Economic Journal, 92(367), 630-653.

Hopenhayn, H. A. (1992). Entry, exit and firm dynamics in long run equilibrium. Econometrica, 60(5), 1127-1150.

Jovanovic, B., \& MacDonald, G. M. (1994). The life cycle of a competitive industry. Journal of Political Economy, 102(2), 322-347.

Klepper, S. (1996). Entry, exit growth and innovation over the product life cycle. American Economic Review, 86(3), 562-583.

Klepper, S., \& Simmons, K. L. (2000). Dominance by birth right: entry of prior radio producers and competitive ramifications in the US television receiver industry. Strategic Management Journal, 21(10/11), 997-1016.

Klepper, S., \& Simmons, K. L. (2005). Industry shakeouts and technological change. International Journal of Industrial Organization, 23(1-2), 23-43.

Mazzucato, M. (2002). The PC industry: new economy or early life-cycle. Review of Economic Dynamics, 5(2), 318-345.

Nigeria Population Commission (NPC). (2010). Census figures of Nigerian population. Retrieved from services.gov.ng/national-population-commission

Nigerian Communications Commission. (2015). Telecommunication statistics. Retrieved from http://www.ncc.gov.ng/

Simons, K. L. (1995). Shakeouts: Firm Survival and Technological Change in New Manufacturing Industries. PhD dissertation, Carnegie Mellon University. 